\title{
The impacts of climate variability on coffee yield in five indonesian coffee production centers
}

\author{
Yeli Sarvina $^{1}$ (D) Tania June $^{2}$ (D), Surjono Hadi Sutjahjo ${ }^{3}$ (D) Rita Nurmalina $^{4}$ (D), Elza Surmaini ${ }^{\text {(D) }}$
}

\author{
${ }^{1}$ Natural Resource and Environmental Management Science Graduate School, IPB University, Bogor, Indonesia and Indonesian Agency for Agricultural Research and Development, \\ Natural Resource \\ ${ }^{2}$ Agrometeorology division Department of Geophysics and Meteorology, Faculty of Mathematics and Natural Sciences, IPB University, Bogor, Indonesia \\ ${ }^{3}$ Department of Agronomy and Horticulture, Faculty of Agriculture, IPB University, Bogor, Indonesia \\ ${ }^{4}$ Department Agribusiness, Faculty of Economics and Management, IPB University, Bogor, Indonesia \\ ${ }^{5}$ Indonesian Agency for Agricultural Research and Development, Bogor, Indonesia \\ Contact authors: yeli_1983@apps.ipb.ac.id; taniajune@apps.ipb.ac.id; Surjonohadisutjahjo@apps.ipb.ac.id; ritanurmalina@apps.ipb.ac.id; elzasurmaini@gmail.com \\ Receivd in April 19, 2021 and approved in July 15, 2021
}

\section{ABSTRACT}

Coffee is an annual crop sensitive to climate variability. Most Indonesian coffee is cultivated on marginal lands that are vulnerable to environmental changes, including climate. Indonesia's climate variability is influenced by several factors, including the monsoon, local aspects, and global climate oscillations such as the EI Niño-Southern Oscillation (ENSO) and the Indian Ocean Dipole (IOD). It is crucial to identify the impacts of climate variability on both the production and the economy to develop adaptative measures. This study aims to determine the effects of global climate variability, namely ENSO and IOD, on coffee production in several Indonesian production centers. It uses annual coffee production data in the five major production centers in Indonesia. The ENSO indicators used in this study were the Oceanic Nino Index (ONI) in the Nino 3.4 region and the IOD indicator in the Dipole Mode Index (DMI). The anomaly analysis approach between neutral years and the extreme ENSO and between normal and IOD extreme phases were applied in this study. The results showed that the effects of ENSO and IOD were different in each region. The highest decline in production occurred in the La-Nina year in almost all production centers. The decline in output in the La-Nina year ranged from 6 to $22 \%$. Meanwhile, the IOD that had a decreasing effect on production was positive IOD with a decrease ranging from 1 to $15 \%$.

Key words: ENSO; IOD; Economy; Climate change.

\section{INTRODUCTION}

Coffee is Indonesia's leading plantation crop. Indonesia has long been recorded as one of the world's major coffee producers. Most coffee plantations in Indonesia are smallholder plantations involving around 1.7 million farmers (Central Bureau of Statistics, 2019). Robusta coffee dominates Indonesia's coffee production, namely $75.4 \%$, and involves 1.23 million farmers. Meanwhile, the remaining $24.6 \%$ is Arabica coffee, involving 542,072 farmers (Directorate of plantation, 2019). Coffee is cultivated in almost all Indonesian provinces, but the leading coffee producing regions are Aceh, North Sumatra, South Sumatra, Lampung, East Java, South Sulawesi, and Bengkulu.

Coffee is an annual crop sensitive to climatic (Bacon et al., 2017; Craparo et al., 2015; Tavares; Giarolla; Chou, 2017). The influence of climate is increasingly felt in the Indonesian coffee production system because most Indonesian coffee is cultivated on marginal land, arid land, which is vulnerable to changes in abiotic environments such as climate (Gunathilaka; Smart; Fleming, 2018). The effect of climate variability on coffee production has been reported in various studies, including (Dula, 2018; Jayakumar; Rajavel; Surendran 2017; Pham; Reardon-Smith; Cockfield, 2019; Tucker; Eakin; Castellanos, 2010). Climate variability was also reported to have contributed to annual coffee crop production (Camargo, 2010; Chengappa; Devika, 2017; Pham; Reardon-Smith; Cockfield, 2019; Zullo et al., 2011).

Couto Júnior et al. (2013) reported that climate determined coffee phenology, therefore, to identify climate variability impact on yield, coffee phenology need to be identified. De Camargo and De Camargo (2001) state that there are six phases in the coffee production cycle. The first two phases are the vegetative phase. The first phase is bud formation, and the second phase is maturation and dormancy (resting). Furthermore, the third phase is marked by flowering, the fourth phase of fruit formation, the fifth phase of fruit ripening, and the sixth phase is the resting phase. Each of these phases requires different microclimate conditions and different water requirements. From the phases mentioned above, there is a critical phase that really determines coffee production. For example, the critical point for fruit formation is the end of the second phase where a dry period is required for flower formation and after that it must be followed by a wet period at the beginning of the third period.

Indonesia's climate variability is mainly influenced by two monsoon systems, namely the Asian and Australian monsoons (Aldrian; Susanto, 2003). In addition to the two periodic monsoon systems, Indonesia's climate variability is also influenced by inter-annual factors of global climate 
oscillations, including El Niño-Southern Oscillation (ENSO) (Aldrian; Susanto, 2003; Arrigo; Wilson, 2008; Hendrawan et al., 2019; Hidayat; Ando, 2018) and the Indian Ocean Dipole (IOD) (Mulyana, 2002). Monsoon is the air masses' movement from Asia and Australia, causing different seasons and peak coffee harvests between regions in Indonesia. ENSO is the sea surface temperature oscillation in the Pacific Ocean indicated by two extreme phases, namely El-Nino and La-Nina. These two intense phases have broadly influenced agricultural production dynamics in most countries, including Indonesia (Arrigo; Wilson, 2008; Boer; Surmaini, 2019; Heino et al., 2019; Sarvina; Sari, 2018). El-Nino causes a very significant decrease in rainfall in most parts of Indonesia, whereas La-Nina causes an increase in rainfall. IOD is the oscillation of sea surface temperature in the Indian Ocean (Saji et al., 1999; Saji; Yamagata, 2003). The extreme phase of IOD is known as the positive IOD phase and the negative IOD. This IOD is also reported to affect agriculture in Indonesia (Aldrian, 2016).

ENSO and IOD's effects on Indonesian agricultural systems are in line with the research results by (Heino et al., 2019), reporting that global climate oscillations affect crop productivity in nearly $2 / 3$ of the world's agricultural areas. All activities and global oscillation systems take place throughout the year, but the magnitude of each system's influence is not the same in every place and can change from year to year. Therefore, studies on this global oscillation's effects must be carried out between regions, periods, and commodities.

Analysis of the impact of climate variability on coffee production is crucial in planning cultivation activities. This analysis will be possible to determine what climate indicators affect production and how to model them. This information is vital for preparing adaptive measures utilizing climate predictions (Sarvina et al., 2020). There are not many studies on the impact of climate variability on coffee production in Indonesia. Since coffee is an annual crop, it is essential to analyze inter-year climate variability such as ENSO and IOD on coffee production. It is assumed that the global climate phenomenon directly affects coffee production, as in the study by (Silva et al., 2020). Consequently, this study aims to identify ENSO and IOD's effects on coffee production in Indonesia's coffee production centers.

\section{MATERIAL AND METHODS}

\subsection{Material}

This study uses coffee production data in Indonesia's central coffee-producing provinces, namely Aceh, North Sumatra, Bengkulu, South Sumatra, and Lampung. Aceh and North Sumatera are two provinces in the north part Sumatera Island while Bengkulu, South Sumatera and Lampang are in the south part Sumatera Island. Climate variability of Sumatera Island is also influenced by (ENSO) (Aldrian; Susanto, 2003; Arrigo; Wilson, 2008; Hendrawan et al., 2019; Hidayat; Ando, 2018) and the Indian Ocean Dipole (IOD) (Mulyana, 2002)

Production data are annual production per district for at least 20 years, depending on data availability. Production data are obtained from provincial reports in numbers, the Central Bureau of Statistics (BPS), and the Ministry of Agriculture. The length of production data and the number of districts analyzed in each province are presented in Table 1 while the map is presented in Figure 1.

Table 1: Study area and data period.

\begin{tabular}{ccccc}
\hline No & Provinces & $\begin{array}{c}\text { Number of } \\
\text { districts }\end{array}$ & Data Period & $\begin{array}{c}\text { Surface } \\
\text { area (ha) }\end{array}$ \\
\hline 1 & Aceh & 20 Districts & $1993-2017$ & 121060 \\
2 & North Sumatera & 20 Districts & $2000-2018$ & 82459 \\
3 & South Sumatera & 11 Districts & $2001-2019$ & 249710 \\
4 & Bengkulu & 10 Districts & $2005-2018$ & 90885 \\
5 & Lampung & 9 Districts & $1998-2001$ & 161416 \\
\hline
\end{tabular}

The climate variability indicators used in this study involved ENSO and IOD. Various research results indicated that the Sumatran region is influenced by these two climate variabilities. This study's ENSO indicator is the Oceanic Nino Index (ONI) in the Nino 3.4 region for a period adjusted to coffee production data in each province. This data is obtained from the National Oceanic and Atmospheric Administration (NOAA, 2019b). ONI is a 3-month average running sea surface temperature (SST) anomaly in the Nino 3.4 region (5oNorth Latitude-5o South Latitude, 120o-170o Longitude West). Meanwhile, the IOD indicator used is the Dipole Mode Index (DMI) from (NOAA, 2019a).

\subsection{Methods}

The La-Niña and El-Niño phases are determined at the threshold of $+/-0.50 \mathrm{C}$. Years in which ONI equal to or greater than 0.5 for five consecutive months are defined as ElNiño years. The intensity is divided into four classes, namely weak (SST 0.5 -0.9), moderate (SST 1-1.4), strong (1.51.9), and very strong (SST greater than 2). IOD has neutral, positive, and negative phases. Anomalous SST between the western equatorial Indian Ocean dan the southeastern equatorial Indian ocean will determine the intensity of IOD. This gradient is called as DMI. A positive IOD (pIDO) occurs when the DMI value is more significant than 0.5 , and a negative IOD (nIOD) occurs when the DMI value is smaller than -0.5 . The years of the ENSO and IOD events are presented in Table 2. 


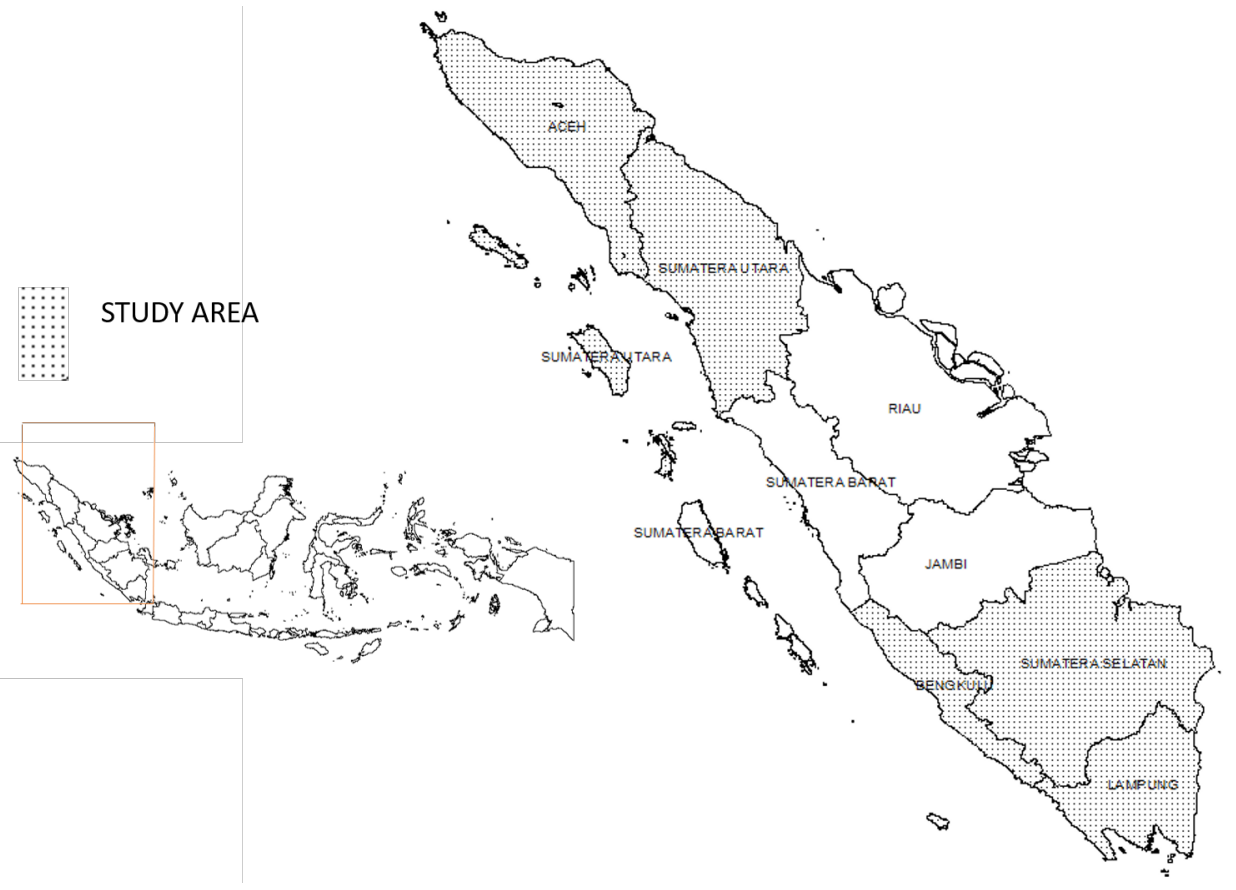

Figure 1: Study area.

Table 2: ENSO and IOD event in years.

\begin{tabular}{cc}
\hline Events & Years \\
\hline \multirow{2}{*}{ Elnino } & Weak: 1994. 2004. 2006.2014.2018 \\
& Moderate: 1991. 2002. 2009 \\
& Strong: 1997.2015 \\
La-Nina & Weak:1995. 2005.2008.2016. 2017 \\
& Moderate: 2011 \\
pIOD & Strong:1998.1999. 2007.2010 \\
nIOD & 1994. 1997. 2006. 2007.2012.2013.2015.2017 \\
\hline
\end{tabular}

Analysis of the impact of climate variability on coffee production generally uses historical production data through two approaches. The first method, the regression method, directly predicts the effects of climate variability indicators on production using historical data (Tack; Ubilava, 2013). The second approach compares the difference (deviation) of output in normal years and extreme climatic conditions (Cirino et al., 2015; Cobon et al., 2016; Ramirez-Rodrigues et al., 2014). Productions in normal and extreme years are presented in boxplot form. In this study we use the anomaly approach.

\section{RESULTS}

Historical data on coffee production in the study area is presented in Figure 2. In general, the average coffee production in Indonesia is around 0.5 tons/ha. This productivity rate is low compared to the productivity of Coffee in Vietnam (2.5 tons/ha), Brazil (1.5) (Food and Agriculture Organization of the United- FAOSTAT, 2019) of the five study areas, Lampung Province has the highest average productivity while the province with the lowest average productivity is Aceh. North Sumatra and South Sumatra have the highest inter-regional production variability. Meanwhile, Bengkulu is listed as the province with the lowest production variability. This increased productivity variability indicates that cultivation techniques and environmental conditions vary between districts.

ENSO had different effects among coffee production centers (Figure 3). In general, La-Nina causes a decrease in productivity in all regions, except Bengkulu Province, with different declining rates. An incredibly significant reduction in productivity during the La-Nina year occurred in Aceh Province, while the lowest productivity decline occurred in Lampung Province. The decline in productivity in El-Nino years only occurs in the provinces of Aceh, North Sumatera and Lampung. Meanwhile, in other regions, there was a slight increase in average years.

The effect of IOD on coffee productivity is shown in Figure 4. Similar to ENSO, the impact of IOD differs among coffee production centers in Indonesia. At the time of pIOD where there was an increase in rainfall, in general, there was a decrease in production except in Aceh. Meanwhile, in nIOD, productivity increased in general, except in North Sumatra and Lampung Province. These results indicate that nIOD and pIOD have different effects. Like ENSO, the different impact of IOD on coffee production might also be determined when the IOD occurs. 


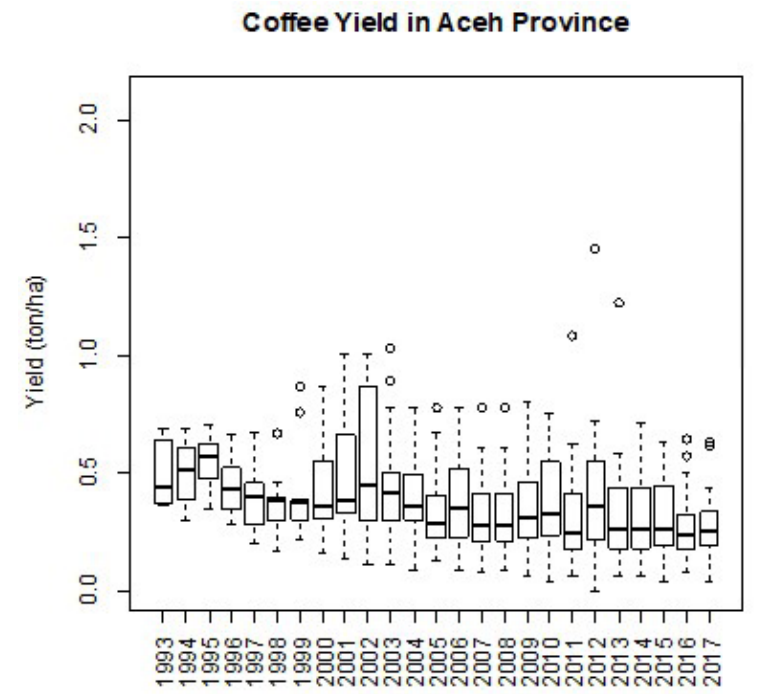

Coffee Yield in South Sumatera Province

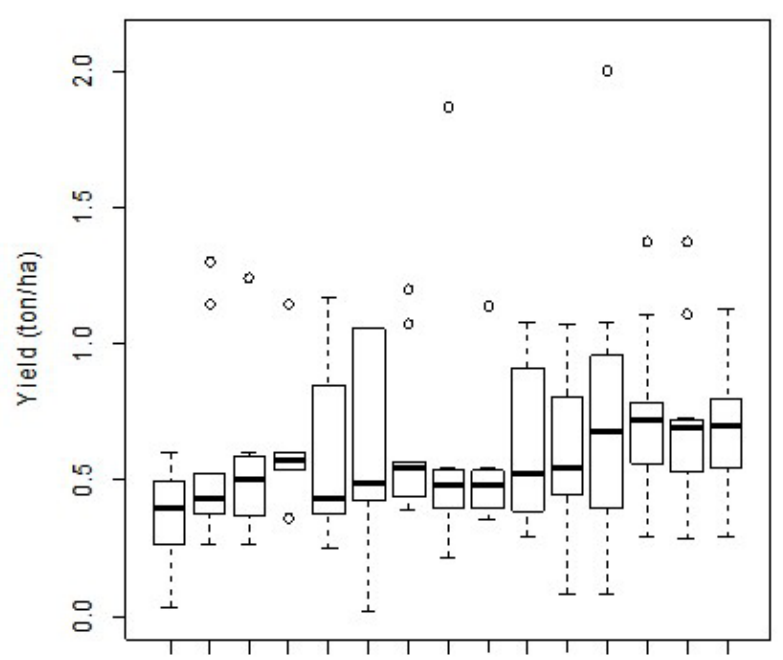

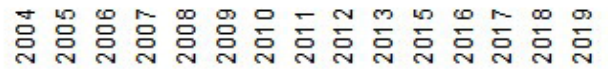

Coffee Yield in Bengkulu Province

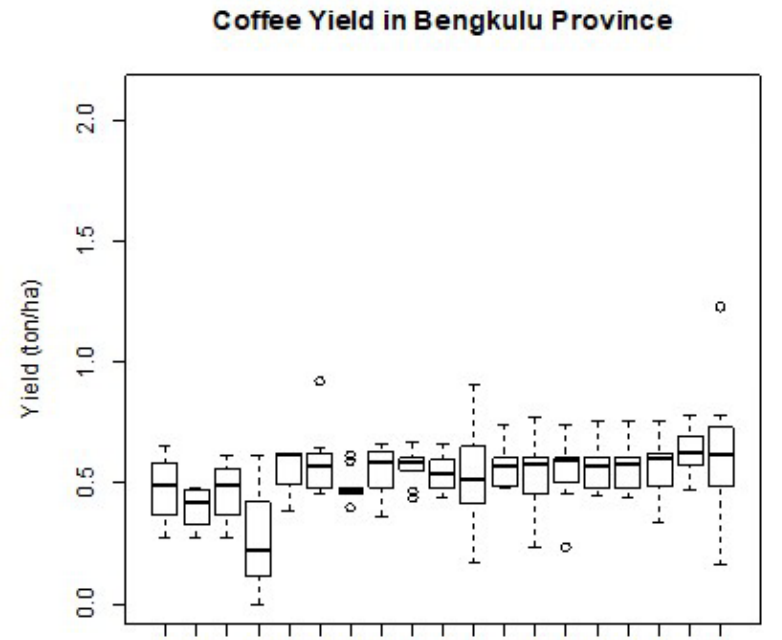

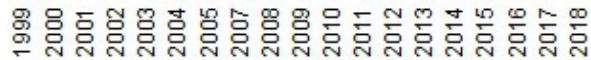

Coffee Yield in North Sumatera Province

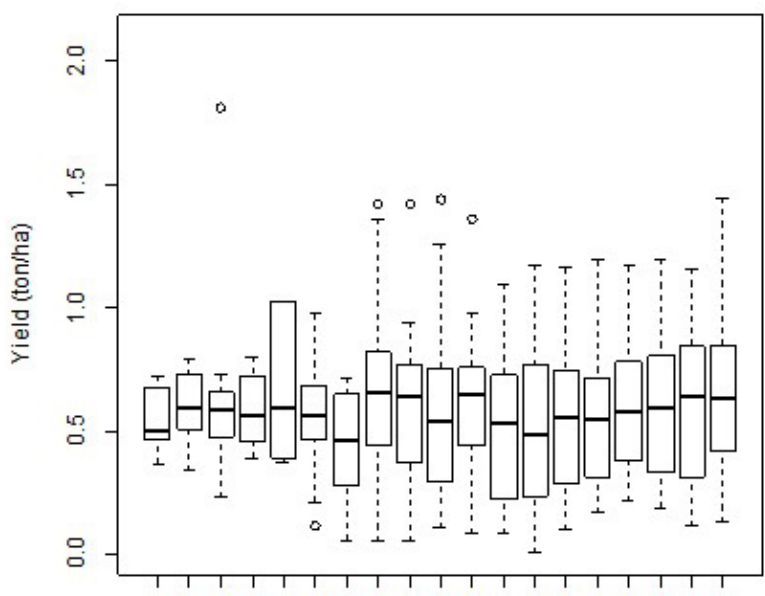

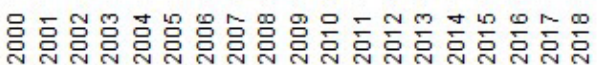

Coffee Yield in Lampung Province

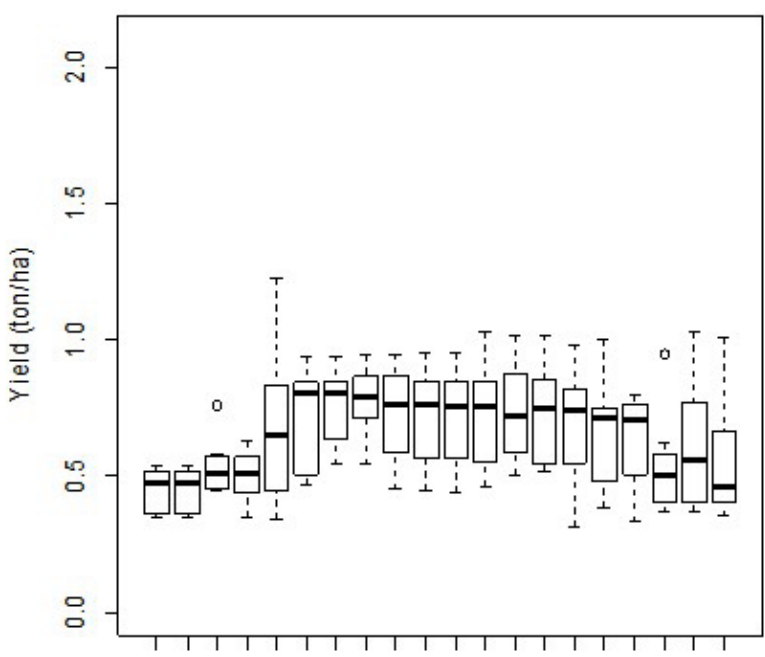

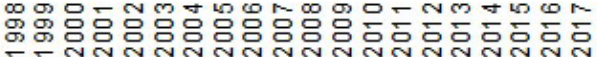




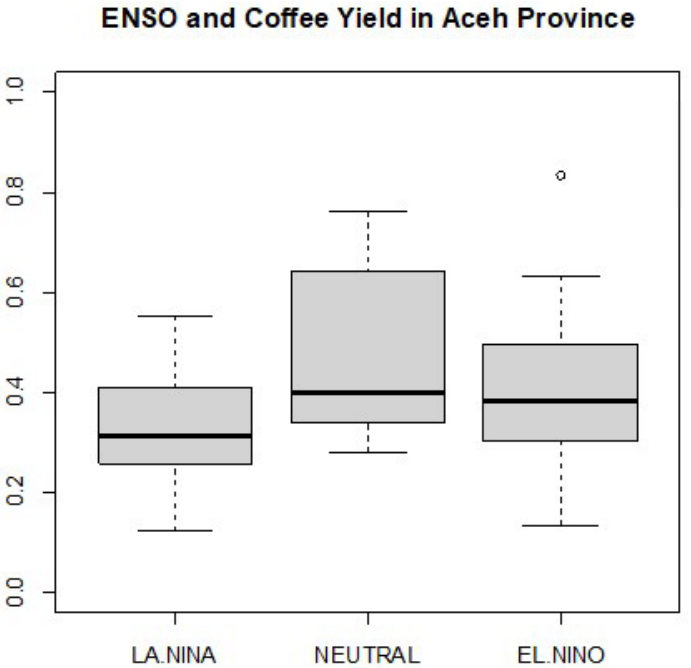

ENSO and Coffee Yield in North Sumatera Province

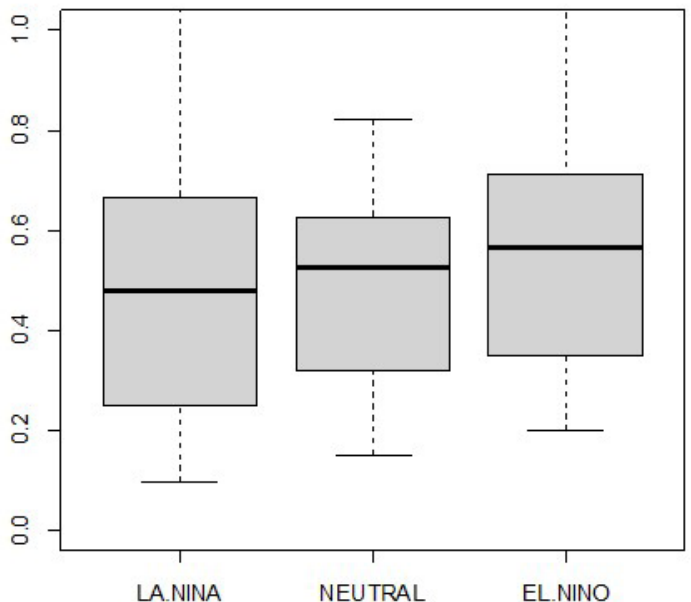

ENSO and Coffee Yield in South Sumatera Province

ENSO and Coffee Yield in Lampung Province
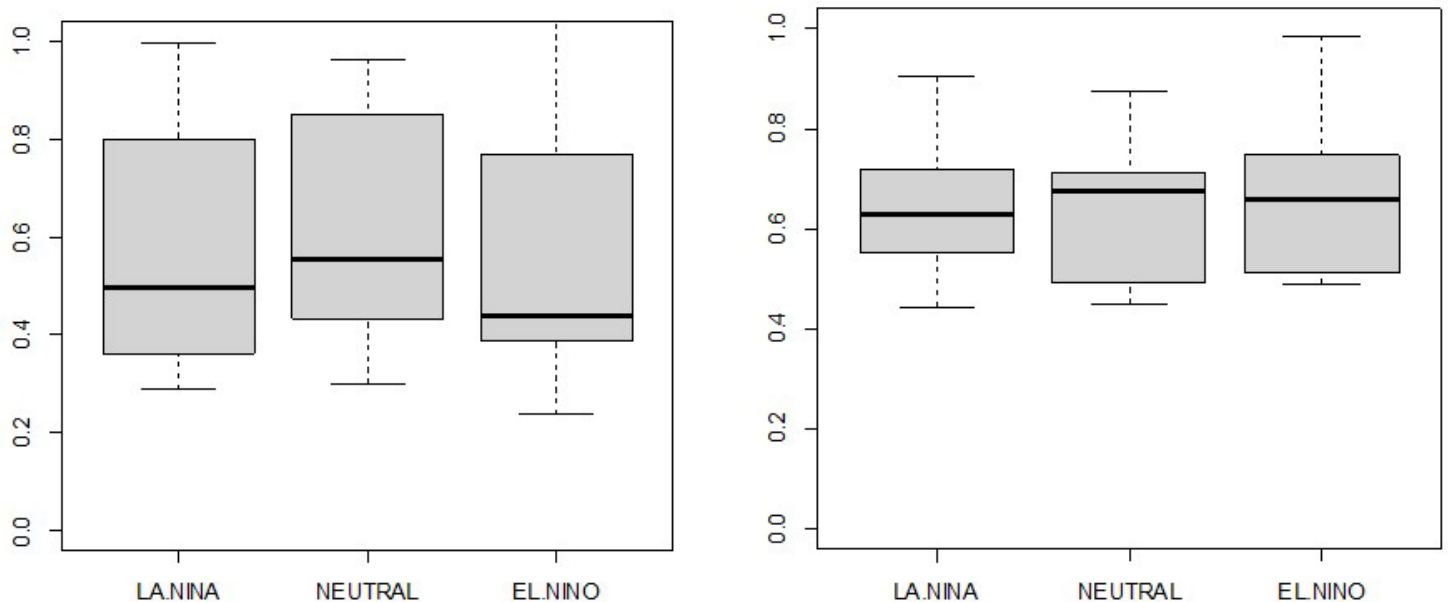

ENSO and Coffee Yield in Bengkulu Province

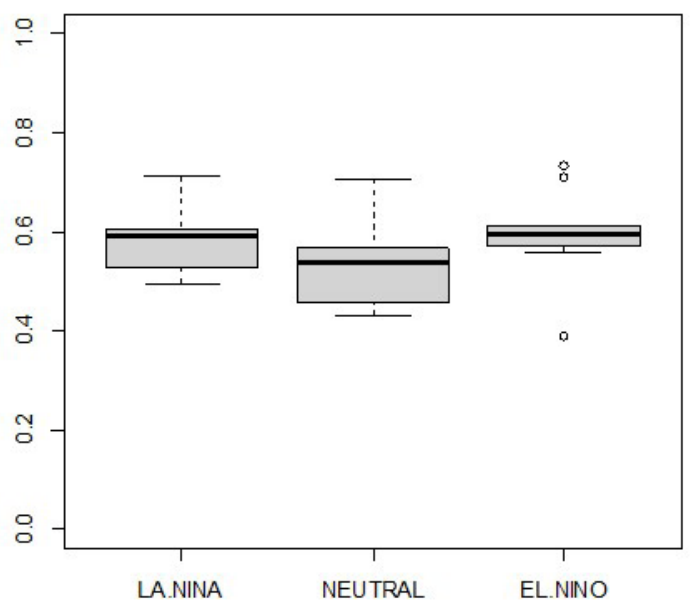

Figure 3: Coffee productivity in La-Nina, El-Nino and Neutral years. 
ENSO and Coffee Yield in Aceh Province

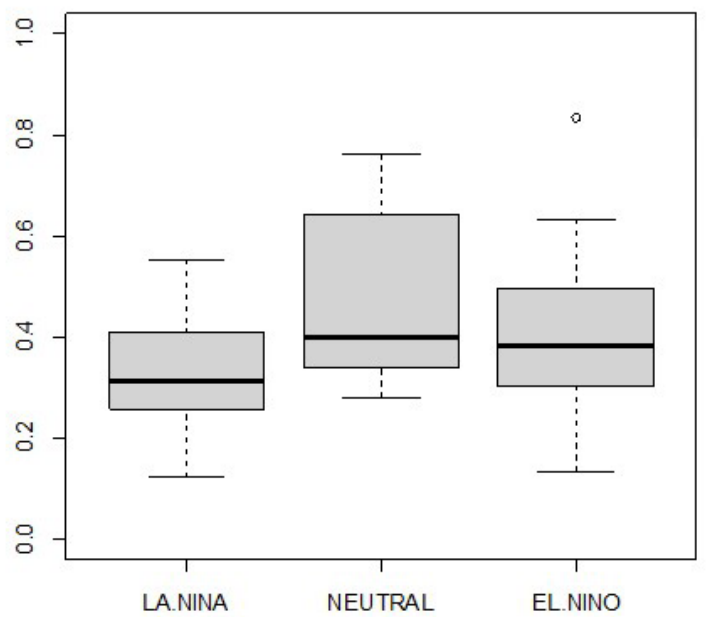

ENSO and Coffee Yield in South Sumatera Province

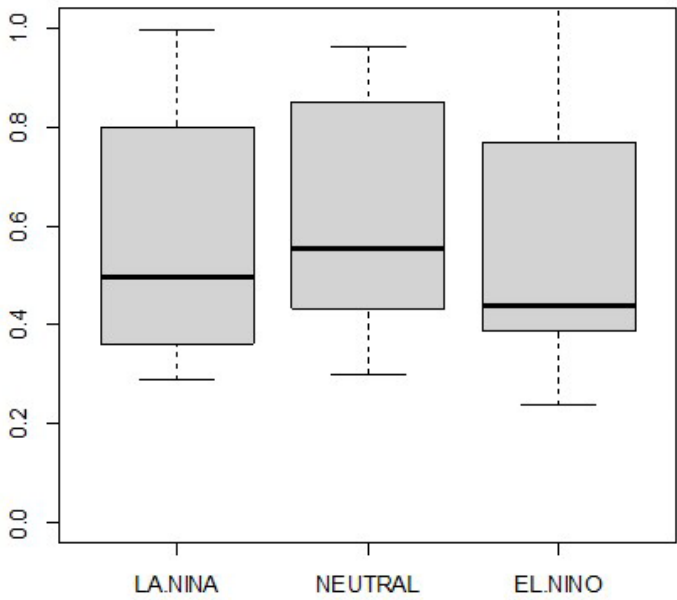

ENSO and Coffee Yield in Bengkulu Province

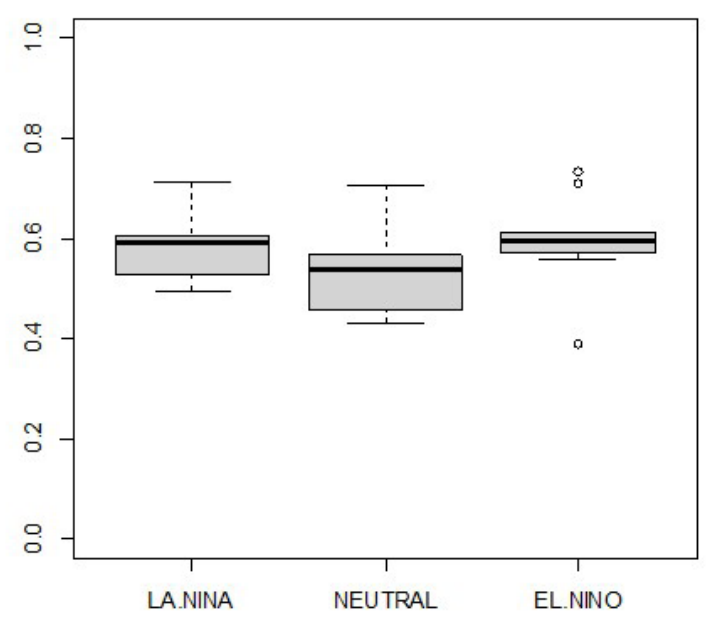

Figure 4: Coffee productivity in pIOD and nIOD years.
ENSO and Coffee Yield in North Sumatera Province

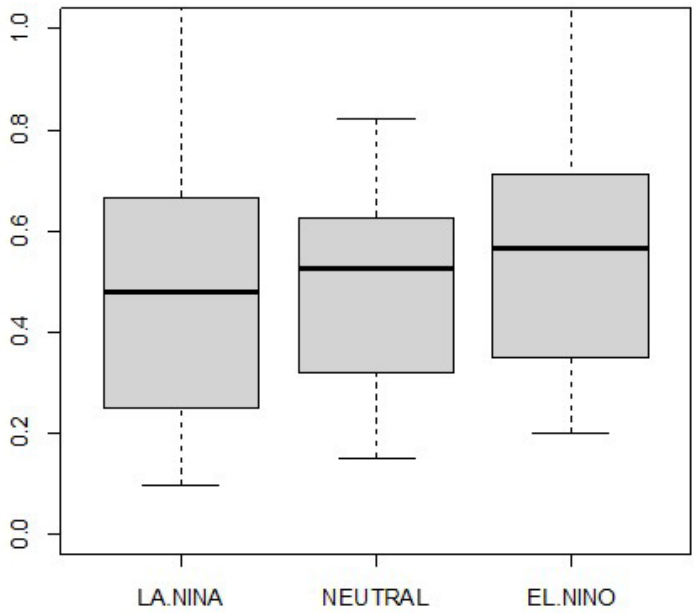

ENSO and Coffee Yield in Lampung Province

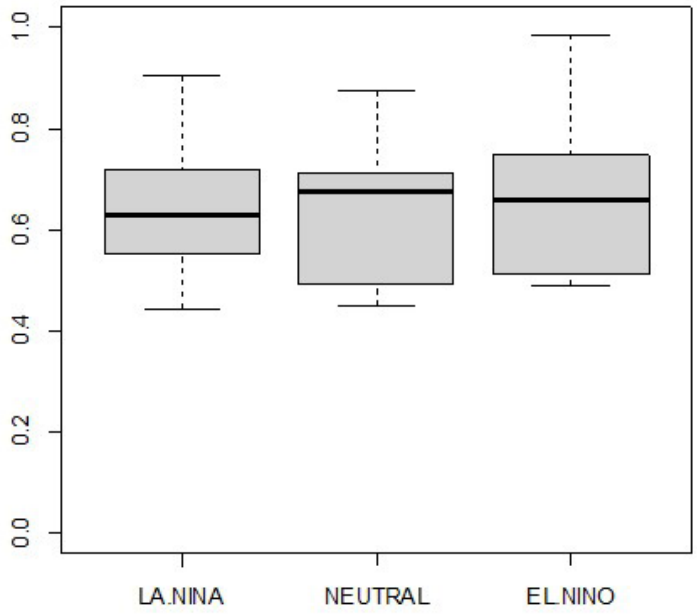


The percentage change in production in ENSO and IOD years in each province is shown in Figure 5. La-Nina has the most significant impact on the decrease in coffee production. In the La-Nina year, the decline in output ranged from 6 to $22 \%$ and in the El-Nino year the decline output ranges from $2-20 \%$. The IOD year that had the most significant impact on the decrease in production was the negative year (nIOD), with drops ranging from 1 to $15 \%$.

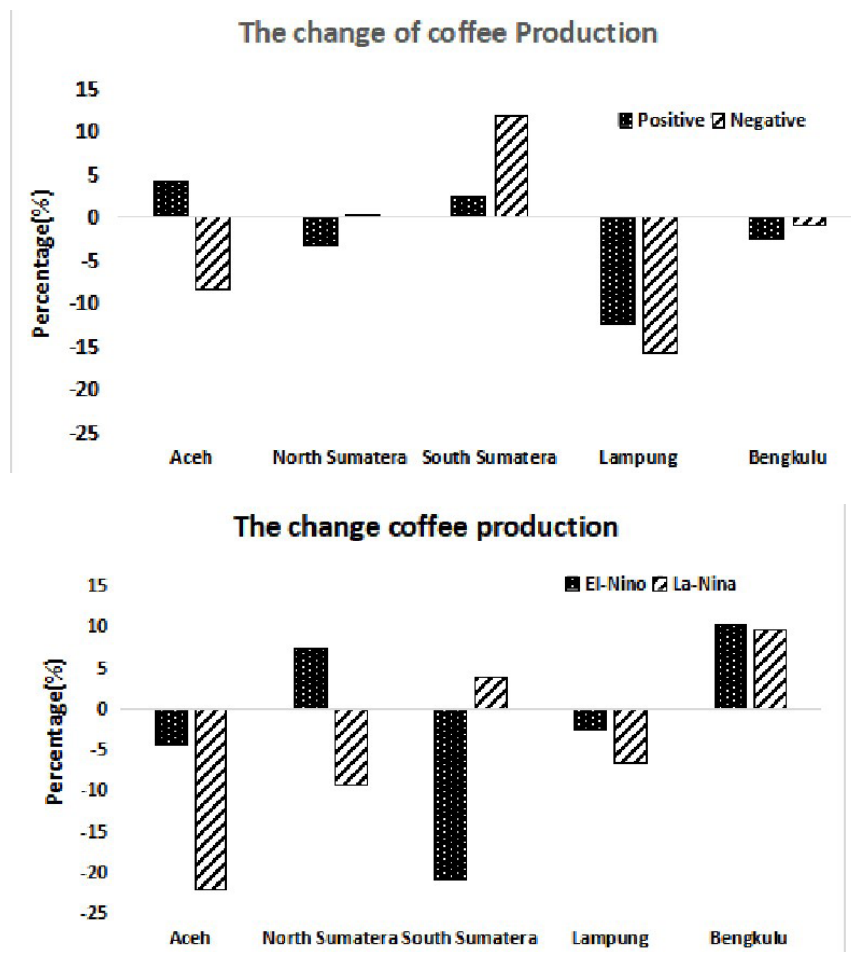

Figure 5: The change coffee production (\%) a) in pIOD and nIOD year and b) in El-Nino and La-Nina Year.

\section{DISCUSSION}

The low productivity of coffee is the main problem of the coffee production system in Indonesia (Sarvina et al., 2020). Low productivity low due to environmental, social-economic factors, institutional, and farm management challenge. Several studies stated that Indonesia's current coffee production has only reached $60 \%$ of its production potential (Wahyudi; Jati, 2012). The Indonesian coffee production could be increased through productivity. Therefore, all factors that influence coffee productivity need to be identified such as environment (climate and soil), technology, etc.

In general, La-Nina causes increased rainfall in Indonesia and longer wet season. On the contrary, El-Nino causes the decreased rain to fall and longer dry season (Nurutami; hidayat, 2016). The decline in productivity in the La-Niña year can be explained through several mechanism. This increase in rainfall will have a significant impact if it occurs when coffee plants need less water. Phase with a small need for water in coffee plants is a critical point for fruit formation, namely at the end of the second phase, where a dry period is required for flower formation (Camargo; Camargo, 2001). Furthermore, (Coffee \& climate, 2015) explained that it takes three months dry period to create plant stress, which is very important in flower formation. Dry months that are longer or shorter than three months can disrupt the growth and development of flowers, affecting production.

If this increase in rainfall occurs when the coffee is in bloom, it can cause the fall of flowers resulting in a reduction in coffee beans (Hameed; Hussain; Suleria, 2018). The decline in production in the La-Nina year can also be caused by an increase in pest and disease attacks because increased rainfall can increase humidity, which is one of the causes of pest and disease attacks (Avelino et al., 2015).

El Nino phase is related to decreasing rainfall and drought. It can disrupt metabolic processes in plants and reduce coffee production. Drought causes stress on plant usually occur and develop slowly. Therefore, in El-Nino phase time factor plays a important role in maintaining of productivity. Farmer can apply technology or add more production input to stabilize productivity.

The aforementioned discussion highlights the importance identifyng the coffee phenological phases to determine the effect of ENSO or IOD in more detail for each region. However, phonological data on coffee in this study area are not available. In general, information on coffee penology in Indonesia has not been continuously observed. Brunsell, Pontes, and Lamparelli (2009) and Couto Júnior et al. (2013) stated that coffee's phenology is highly dependent on agroclimatic conditions. Therefore, one approach that can be taken to identify the impact of climate change and variability on coffee production is determining plant phenology.

In the La-Nina year, the decline in coffee production ranged from 6 to $22 \%$ and in the El-Nino year the decline production ranges from $2-20 \%$. The IOD year that had the most significant impact on the decrease in production was the negative year (nIOD), with drops ranging from 1 to $15 \%$. The results of the analysis of the impact of ENSO on production in this study were higher than those of Bastianin, Lanza and Manera (2018) stating that the effects of ENSO on a regional scale and a short period are around $2.2 \%$. Meanwhile, on a long-term scale, it is approximately $8.3 \%$.

\section{CONCLUSIONS}

The extreme phase of ENSO has different impacts on coffee production centers in Indonesia. In general, the most significant effect of ENSO on production occurred in the LaNina year, where the decline in production occurred in almost all central provinces with a decrease of output ranging from 6 
to $22 \%$. Similar to ENSO, IOD also has different effects among areas. The IOD year that had the most significant impact on the decrease in production was the negative year (nIOD) with a decrease of output range from $1-15 \%$.

\section{ACKNOWLEDGEMENTS}

The author would like to give a huge appreciation to Indonesian Agency for Research and Development (IARD) provided funding of this research.

\section{REFERENCES}

ALDRIAN, E. Sistem peringatan dini menghadapi iklim ekstrem. Jurnal Sumberdaya Lahan, 10(2):79-90, 2016.

ALDRIAN, E.; SUSANTO, D. R. Identification of three dominant rainfall regions within Indonesia and their relationship to sea surface temperature. International Journal of Climatology, 23(12):1435-1452, 2003.

ARRIGO, R. D.; WILSON, R. El nino and indian ocean influences on indonesian drought: Implication for forecasting rainfall and crop productivity. International Journal of Climatology, 28(5):611-616, 2008.

AVELINO, J. et al. The coffee rust crises in Colombia and Central America (2008-2013): Impacts, plausible causes and proposed solutions. Food Security, 7:303-321, 2015.

BACON, C. M. et al. Vulnerability to cumulative hazards: Coping with the coffee leaf rust outbreak, drought, and food insecurity in Nicaragua. World Development, 93:136-152, 2017.

BASTIANIN, A.; LANZA, A.; MANERA, M. Economic impacts of El Niño southern oscillation: Evidence from the Colombian coffee market. Agricultural Economics, 49(5):623-633, 2018.

BOER, R.; SURMAINI, E. Economic benefits of ENSO information in crop management decisions: Case study of rice farming in West Java, Indonesia. Theoretical and Applied Climatology, 139:1435-1446, 2019.

BRUNSELL, N. A.; PONTES, P. P. B.; LAMPERI, R. A. C. Remotely sensed phenology of coffee and its relationship to yield remotely sensed phenology of coffee and its relationship to yield. GIScience \& Remote Sensing, 46(3):289-304, 2009.

CAMARgo, A. P. de.; CAMARGO, M. B. P. de. Definition and outline for the phenological phases of arabic coffee under Brazilian tropical conditions. Bragantia, 60(1):65$68,2001$.
CAMARGO, M. B. P. The impact of climate variability and climate change on arabic coffee crop in Brazil. Bragantia, 69(1):239-247, 2010.

\section{CENTRAL BUREAU OF STATISTICS. Indonesian}

Coffee Statistics. Jakarta. 2019. Available in: $<$ https:/www.bps.go.id/publication/2020/12/02/ de27ead7c1c7e29fd0aa950d/statistik-kopiindonesia-2019.html >. Access in: August, 09, 2021.

CHENGAPPA, P. G.; DEVIKA, C. M. Climate variability concerns for the future of coffee in India: an exploratory study. International Journal of Environmental, Agriculture and Biotechnology, 1(4):819-826, 2017.

CIRINO, P. H. et al. Assessing the impacts of ENSO-related weather effects on the Brazilian agriculture. Procedia Economics and Finance, 24:146-155, 2015.

COBON, D. H. et al. Food shortages are associated with droughts, floods, frosts and ENSO in Papua New Guinea. Agricultural Systems, 145:150-164, 2016.

COFFEE \& CLIMATE (C\&C). Climate change adaptation in coffee production. Germany: coffee \& climate. 2015. $184 p$.

COUTO JÚNIOR, A. F. et al. Phenological characterization of coffee crop (Coffea arabica L.) from MODIS time series. Revista Brasileira de Geofisica, 31(4):569-578, 2013.

CRAPARO, A. C. W. et al. Coffea arabica yields decline in Tanzania due to climate change: Global implications. Agricultural and Forest Meteorology, 207:1-10, 2015.

DE CAMARGO, Â. P.; DE CAMARGO, M. B. P. Definição e esquematização das fases fenológicas do cafeeiro arábica nas condições tropicais do Brasil. Bragantia, 60(1):65-68, 2001.

DIRECTORATE OF PLANTATION. Tree Crop Estate Statistics of Indonesia. Direktorat Jenderal Perkebunan Kementerian Pertanian, 2019. 96p.

DULA, T. Climate variability and determinants of its adaptation strategies: The case of coffee (coffea arabica) producer farmers at abeshege woreda, Ethiopia. Agricultural Research \& Technology, 7(3): 556028, 2018.

FOOD AND AGRICULTURE ORGANIZATION OF THE UNITED - FAOSTAT. Database. 2019. Availabe in: $<$ http://faostat3.fao.org/home/E $>$. Access in: August, 09, 2021. 
GUNATHILAKA, R. P. D. et al. Adaptation to climate change in perennial cropping systems: Options, barriers and policy implications. Environmental Science \& Policy, 82:108-116, 2018.

HAMEED, A.; HUSSAIN, S. A.; SULERI, H. A. R. “Coffee Bean-Related" agroecological factors affecting the coffee. In: MERILLON, J. M.; RAMAWAT, K. (eds). CoEvolution of secondary metabolites. Reference Series in Phytochemistry: Cham: Springer Nature, p. 1-67, 2018.

HEINO, M. et al. A multi-model analysis of teleconnected crop yield variability in a range of cropping systems. Earth System Dynamics, 11:113-128, 2019.

HENDRAWAN, I. G. et al. The interanual rainfall variability in Indonesia corresponding to El Niño Southern Oscillation and Indian Ocean Dipole. Acta Oceanologica Sinica, 38(7):57-66, 2019.

HIDAYAT, R.; ANDO, K. Rainfall variability over Indonesia and its relation to ENSO/IOD: Estimated using Jra-25/ Jcdas. Agromet, 28(1):1-8, 2018.

JAYAKUMAR, M.; RAJAVEL, M.; SURENDRAN, U. Impact of climate variability on coffee yield in India with a micro-level case study using long-term coffee yield data of humid tropical Kerala. Climatic Change, 145:335:349, 2017.

MULYANA, E. Pengaruh dipole mode terhadap curah hujan di Indonesia. Jurnal Sains \& Teknologi Modifikasi Cuaca, 3(1):39-43, 2002.

NURUTAMI, M. N.; HIDAYAT, R. Influence of IOD dan ENSO to Indonesian rainfall variability: Role of atmosphere-ocean interaction in the Indo-Pacific sector. Procedia Environmetal Science, 33:196-203, 2016.

NOAA. Dipole mode index (DMI). 2019a. Availavbe in: $<$ https://stateoftheocean.osmc.noaa.gov/sur/ind/dmi.php $>$. Access in: August, 09, 2021.

NOAA. El Niño Southern Oscillation (ENSO). 2019b. Availabe in: https://origin.cpc.ncep.noaa.gov/products/ analysis_monitoring/ensostuff/ONI_v5.php. Access in: August, 09, 2021.

PHAM, Y.; REARDON-SMITH, K.; COKFIELD, G. The impact of climate change and variability on the coffee production: A systematic review. Climatic Change, 156:609-630, 2019.
RAMIREZ-RODRIGUES, M. A. et al. Climate risk management tailoring wheat management to ENSO phases for increased wheat production in Paraguay. Climate Risk Management, 3:24-38, 2014.

SAJI, N. H. et al. A dipole mode in the tropical Indian ocean. Nature, 401:360-363, 1999.

SAJI, N. H.; YAMAGATA, T. Possible impac ts of Indian Ocean Dipole mode events on global climate. Climate Research, 25(2):151-169, 2003.

SARVINA, Y. et al. Strategy for increasing coffee productivity and adaptation on climate change and climate variability through cultivation calendar. Journal sumber daya lahan, 14(2):65-78, 2020.

SARVINA, Y.; SARI, K. Dampak ENSO terhadap produksi dan puncak panen durian di Indonesia (enso impacts on production and peak harvest season of durian in Indonesia). Jurnal Tanah Dan Iklim, 41(2):149-158, 2018 .

SILVA, K. A. et al. Influence of El Niño and La Niña on coffee yield in the main coffee-producing regions of Brazil. Theoretical and Applied Climatology, 139:(3-4): 1019-1029, 2020.

TACK, J.; UBILAVA, D. The effect of El niño Southern Oscillation on US Corn production and downside risk. Climatic Change, 121(4):689-700, 2013.

TAVARES, S. et al. Climate change impact on the potential yield of Arabica coffee in southeast Brazil. Regional Environmental Change, 18:873-883, 2017.

TUCKER, C.; EAKIN, H.; CASTELLANOS, E. J. Perceptions of risk and adaptation: Coffee producers, market shocks, and extreme weather in Central America and Mexico. Global Environmental Change, 20:23-32, 2010 .

WAHYUDI, T.; JATI, M. Challenges of sustainable coffee certification in Indonesia. p. 1-14, 2012. Available in: $<$ http://www.ico.org/event_pdfs/seminar-certification/ certification-iccri-paper.pdf $>$. Access in: August, 09, 2021.

ZULLO, J. et al. Potential for growing Arabica coffee in the extreme south of Brazil in a warmer world. Climatic Change, 109:535-548, 2011. 